Journal of Innate

Immunity
J Innate Immun 2012;4:260-272

DOI: $\underline{10.1159 / 000332435}$
Received: May 4, 2011

Accepted after revision: August 31, 2011

Published online: November 22, 2011

\title{
The Role of Complement in the Development and Manifestation of Murine Atherogenic Inflammation: Novel Avenues
}

\author{
Lorenza Francescut $^{\mathrm{a}}$ Tanja Steiner $^{\mathrm{b}}$ Simon Byrne ${ }^{\mathrm{a}}$ Katherine Cianflone ${ }^{c}$ \\ Sheila Francis ${ }^{\mathrm{b}}$ Cordula Stover $^{\mathrm{a}}$ \\ ${ }^{a}$ Department of Infection, Immunity and Inflammation, University of Leicester, Leicester, and ${ }^{b}$ Department of \\ Cardiovascular Science, University of Sheffield Medical School, Sheffield, UK; ${ }^{C}$ Centre de Recherche IUCPQ, \\ Laval University, Quebec, Que., Canada
}

\section{Key Words}

Complement $\cdot$ Mouse models $\cdot$ Atherosclerosis

\begin{abstract}
Atherosclerosis is a chronic progressive inflammatory disease which manifests in the arterial vascular tree. It is a major cause of cardiovascular morbidity and contributes significantly to mortality in the developed world. Triggers for this inflammatory process are elevated levels of cholesterol, bacterial infection and obesity. The immune response in atherosclerosis is essentially pro-atherogenic, leading to lipid accumulation and cellular changes within the arterial wall. Small-animal models of atherosclerosis are used to study the relevance of candidate factors (cells, genes, diets) in the development and progression of lesions. From a multidisciplinary viewpoint, there are challenges and limitations to this approach. Activation of complement determines or modifies the outcome of acute and chronic inflammation. This review dissects the role of complement in the early development as well as the progressive manifestation of murine atherosclerosis and the advances in knowledge provided by the use of specific mouse models. It gives a critical overview of existing models, analyses seemingly conflicting results obtained with complement-deficient mouse models,
\end{abstract}

highlights the importance of interrelationships between pro-coagulpant activity, adipose tissue, macrophages and complement, and uncovers exciting avenues of topical research.

Copyright $\odot 2011$ S. Karger AG, Basel

\section{Introduction}

Atherosclerosis is a metabolically induced and genetically influenced chronic inflammatory condition of the arteries. The characteristic pathologic manifestation is the atheroma, i.e. arterial intima thickened by a fatty deposit and inflammatory cells. Oxidatively modified lowdensity lipoproteins (oxLDLs) are intimately involved in this process. Their presence is often associated with hyperlipoproteinaemia (elevated levels of lipoproteins in blood), a recognised risk factor for the development of arteriosclerosis. The prevalence of hyperlipoproteinaemia in the population is high, and it may be secondary to diabetes, gout and obesity or of hereditary origin. Bound by scavenger receptors, oxLDLs activate endothelial cells to produce pro-inflammatory mediators, leading to adhesion of leukocytes. Oxidation of LDL, mediated in the arterial wall and aggravated by dietary intake of oxidised 
Fig. 1. Pathways of complement activation. MASP $=$ MBL-associated serine protease.

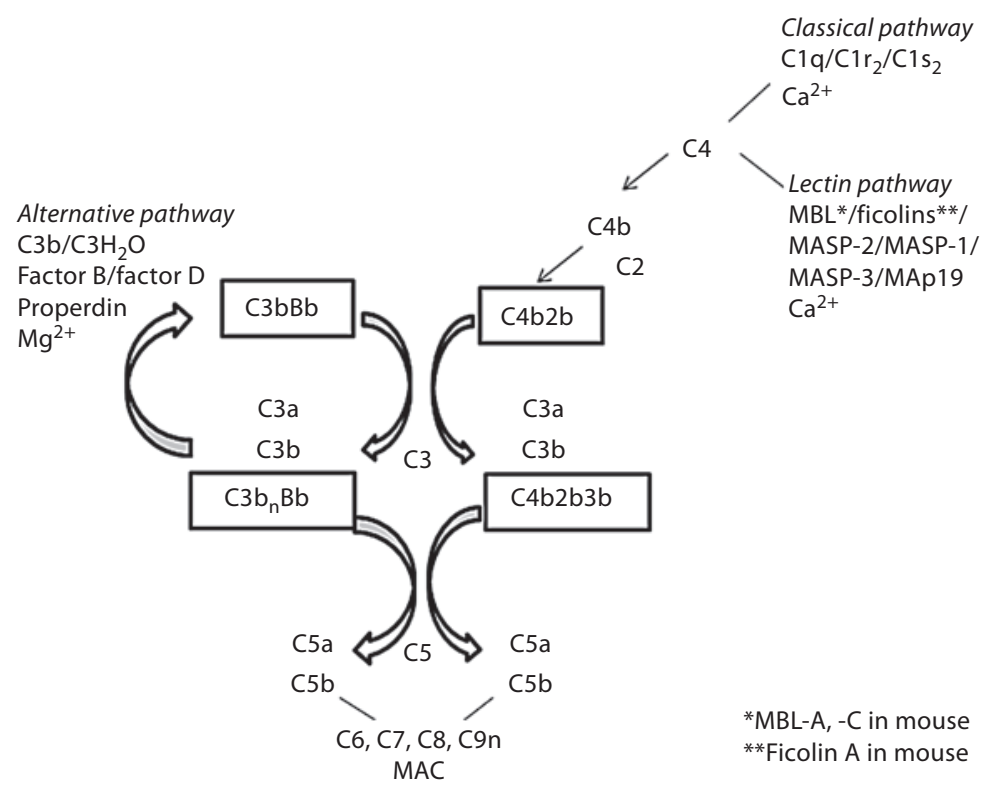

fatty acid and cholesterol [1], leads to the formation of foam cells (macrophages laden with cholesterol) and interferes with the activity of an endothelial coagulation inhibitor [through modification and degradation of tissue factor (TF) pathway inhibitor], thereby promoting local coagulation [2].

There is no single target to ameliorate this disease; once atherosclerosis is diagnosed, attempts are made to limit the progress of the disease, such as treating co-morbidities (dyslipidaemia, hypertension and diabetes mellitus), influencing other factors known to precipitate disease (platelet aggregation) and managing complications of the disease (stroke, myocardial infarction, embolism and aneurysm). Because atherosclerosis is the leading cause of death in the developed world and of growing importance in the developing world, novel treatment approaches are sought, using genomic studies and expression profiling in cardiovascular disease. Expression studies in humans have documented an inflammatory component of atherosclerotic disease that may be modulated by cholesterollowering drugs $[3,4]$. Currently, selective targeting of chemokines and their receptors is being discussed for pharmacologic treatment of atherosclerosis [5].

Innate and adaptive immune mechanisms play a role in both the initiation and progression of atherosclerotic disease. This review focuses on the contribution made by complement in the development and manifestation of murine atherosclerosis.

Complement comprises defined zymogens which are activated in a hierarchical cascade on foreign or altered self surfaces via the classical pathway (CP), lectin pathway (LP) or alternative pathway (AP) [6]. Activation is triggered by binding of $\mathrm{C} 1$ to bound immunoglobulins (Igs) (CP) or binding of the lectin recognition molecule mannose-binding lectin (MBL) or ficolins to surface carbohydrates (LP), leading to cleavage of $\mathrm{C} 4$ and $\mathrm{C} 2$, a necessary step in the activation of $\mathrm{C} 3$, which is a central feature of the complement system because of the potency of $\mathrm{C} 3 \mathrm{ac}-$ tivation fragments. The AP (with zymogens factors B and $\mathrm{D}$ and positive regulator properdin) primarily amplifies the activation of $\mathrm{C} 3$ (fig. 1). Opsonisation and phagocytosis are mediated by $\mathrm{C} 3$ fragments and their cellular receptors (such as CR1, the integrins CR3 and CR4, and the C3b-binding receptor of the Ig superfamily CRIg). Complement-mediated chemoattraction occurs as a consequence of the cleavage of $\mathrm{C} 3$ and subsequently $\mathrm{C} 5$ via the release of $\mathrm{C} 3 \mathrm{a}$ and $\mathrm{C} 5 \mathrm{a}$ and their desArg components $\left(\mathrm{C} 3 \mathrm{a}^{\mathrm{desArg}}, \mathrm{C} 5 \mathrm{a}^{\mathrm{desArg}}\right)$ and relevant receptors, C3aR, C5aR and C5L2, on inflammatory cells. Non-enzymatic assembly of C5b, C6, C7, C8 and C9 leads to insertion into membranes (in the absence of down-regulators) as the membrane attack complex (MAC; fig. 1). 
With regard to atherosclerotic lesions, complement anaphylatoxins $\mathrm{C} 3 \mathrm{a}$ and $\mathrm{C} 5 \mathrm{a}$ bind to receptors expressed by plaque intima macrophages, $\mathrm{T}$ cells, mast cells, endothelial cells and medial smooth muscle cells and therefore may have a role in orchestrating the inflammatory component of atherosclerosis. In vitro, oxLDL seems to activate complement directly, as measured by the production of sC5b-9, involving AP and CP activation $[7,8]$. The net effect of complement activation distal of protein C3 was thought to promote maturation of atherosclerotic lesions, based on immunohistochemical findings obtained with an LDL receptor (LDLR) $)^{-/-} / \mathrm{C}^{-/-}$mouse line showing lower smooth muscle and collagen content of atherosclerotic lesions [9]. A non-specific complement inhibitor has been tested in mice with the aim of limiting the disease phenotype; treatment of high-fat diet (HFD)-fed apolipoprotein $\mathrm{E}(\mathrm{ApoE})^{-/-} / \mathrm{LDLR}^{-/-}$mice with recombinant Vaccinia virus complement control protein (VCP; a secreted viral protein which has been shown to block progression of the AP, LP and CP of complement activation) produced a significant reduction in the aortic lesion area compared to control HFD-fed ApoE ${ }^{-/-} / \mathrm{LDLR}^{-/-}$mice when administered once a week for 7 weeks [10]. The mode of action of the purified protein was not investigated, so while interference with complement activation is one possible mechanism via which the extent of the lesion is limited, binding of VCP to heparin is another, because this interaction may competitively inhibit binding of chemokines to endothelial cells. VCP, through its resemblance to host proteins containing complement control protein modules (such as CD55, C4bBP, CD46), is thought to be of low immunogenicity, so it appears unlikely that antibodies raised to VCP are confounders in the positive outcome of this treatment [11].

Blockers which interfere with complement activation or signalling could thus be suitable tools to target features of atheroma development.

ApoE- and LDLR-deficient mice were generated by gene-specific targeting to study the pathogenesis of atherosclerotic disease [12]. LDLR is a cell surface receptor which mediates the endocytosis and hepatic clearance of LDL, whereas ApoE transports lipoprotein and cholesterol and has a high affinity for the LDLR and ApoE receptor. Both ApoE and LDLR are necessary for the clearance of lipoproteins. ApoE ${ }^{-/-}$mice have an increased level of total plasma cholesterol, which is exaggerated on a cholesterogenic Western-type diet (21\% fat, HFD). The development of atherosclerosis is primarily linked to the extent of hypercholesterolaemia [13]. Very low-density lipoprotein and intermediate-density lipoprotein fractions are increased, and mice demonstrate an early onset of atheromatous lesions [14], which manifest throughout the arterial tree. These lesions are significantly more pronounced in $\mathrm{ApoE}^{-/-}$mice than in the HFD-fed wild-type strain C57BL/6 [15]. $\mathrm{LDLR}^{-/}$mice have increased levels of intermediate-density lipoprotein and LDL on normal chow [16] and produce a milder atherosclerotic phenotype when fed an HFD [15]. ApoE*3-Leiden mice represent the third model used to study the development of atherosclerotic lesions and are transgenic for a human ApoE mutant (ApoE*3) which binds defectively to LDLR, leading to hyperlipoproteinaemia.

In the majority of study protocols (HFD for up to 40 weeks), the murine models allow investigation of atheromatous plaque development but not of progression to rupture of the fibrous cap [15]. This remains a limitation of the mouse models because it is the late phase of atherosclerosis which causes life-threatening symptoms in humans. However, one study which analysed $\mathrm{ApoE}^{-/-}$mice in an extended feeding protocol (HFD for 59 weeks) showed significant rupture and sudden death, which most likely was due to thrombotic embolism [17].

Infections exacerbate the development of atherosclerosis [18], and mouse models are starting to be used to analyse the infectious contribution to the atherosclerotic phenotype. However, it may be the overall lifetime pathogen burden that determines the development and progression of human atherosclerotic disease rather than episodic events replicated in the animal models. Because of the evidence of Chlamydia pneumoniae within atheromatous lesions [19] and elevated anti-C. pneumoniae titres in patients with cardiovascular disease, the influence of long-term antibiotic treatment on the incidence of cardiovascular events was investigated in patients. Overall, large-scale clinical trials over at least 10 years did not support a wide application of this treatment approach [20]. Common, functional gene polymorphisms for MBL, which binds to C. pneumoniae, may be relevant disease modifiers.

\section{Mouse Models of Atherosclerosis Reveal a Role of Complement}

The use of $\mathrm{LDLR}^{-/-}$and $\mathrm{ApoE}^{-/-}$mouse models in combination with complement-deficient mouse lines (or cells) has advanced the understanding of the role of complement in the development of atheromatous lesions. Different Western-type HFDs have been used to generate atherosclerotic lesions in these strains. ApoE*3-Leiden 
mice fed a high-cholesterol diet had up-regulated expression of complement C1q, C1qR, C3aR and C9 [21], and $\mathrm{LDLR}^{-/-}$mice fed an HFD showed a significant increase in the expression of complement $\mathrm{C} 3$, factor $\mathrm{D}$ and properdin compared to $\mathrm{LDLR}^{-/-}$mice fed normal chow [22]. Table 1 gives an overview of phenotypic observations in complement-deficient mice on an $\mathrm{ApoE}^{-/-}, \mathrm{LDLR}^{-/-}$or $\mathrm{ApoE}^{-/-} / \mathrm{LDLR}^{-/-}$compound-deficient background. The types of diet and lengths of studies vary and complicate a direct comparison. Nevertheless, the following conclusion may be drawn: in the development of lesions, the presence of Clq (recognition component of the $\mathrm{CP}$ ), $\mathrm{MBL}$ (recognition component of the LP), C3 (central component of the complement activation cascades) and CD59 (called protectin because it inhibits insertion of MAC) may be protective [23-28]. While the membrane-bound down-regulator of complement activation CD55 (decay accelerating factor, dissociates C3 and C5 convertases) regulates lesional lipid deposition in $\mathrm{LDLR}^{-/}$mice on an HFD [29], development of lesions is attenuated in ApoE ${ }^{-/-}$mice on an HFD in the absence of CD55 [30].

By contrast, C6 (part of MAC) [23], C3a receptor C3aR [31] and factor B (Bf; of the AP) [32] appear to exacerbate disease during HFD. In studies analysing an early and later time point, the effect of complement deficiency on an atherosclerosis-prone genetic background manifests within the first 10-16 weeks of an HFD. Lesions may then progress [24], stagnate [23-25, 33] or approach the wildtype phenotype [33]. Therefore, the interpretation of phenotypes caused by different diet regimens is restricted to the particular time points of observation.

The principle dual functionality of complement working either in a predominately atheroprotective or proatherogenic manner has previously been concluded from mice lacking specific complement components and also from analyses of immunohistochemical staining of atherosclerotic lesions and levels of complement components in patients [34].

The lesion-limiting effect of CD59 compared to C1q is noted earlier in the disease ( 8 vs. 12 weeks) in studies which use similar diets ( $21 \%$ pork lard and $0.15 \%$ cholesterol vs. normal chow with $0.15 \%$ cholesterol and $20 \%$ butter fat). The contribution of complement C5 to disease development and manifestation appears to be small [35]. To deduce the role of MBL-A and -C, $\mathrm{LDLR}^{-/-}$mice chimeric for MBL-A/- $\mathrm{C}^{-/-}$bone marrow were generated and compared to $\mathrm{LDLR}^{-/}$mice injected with MBL-A/ $-\mathrm{C}^{+/+}$bone marrow cells [27]. MBL-A/- $\mathrm{C}^{-/-}$macrophages show decreased apoptotic clearance or less phagocytic ability compared to wild-type macrophages and may co-

Complement in Diet-Induced Murine

Atherosclerosis determine the greater plaque area with the former cells. $\mathrm{Clq}$ may be involved in an atheroprotective way via two mechanisms, namely apoptotic body removal and binding to natural antibodies, which are protective in the development of atherosclerosis because of their ability to inhibit the uptake of oxLDL by macrophages [36]. Serum IgM-deficient/LDLR ${ }^{-/-}$mice have larger aortic lesions compared to $\mathrm{Clq}^{-/-}$mice but display a similar phenotype with regard to cholesterol accumulation and smooth muscle cell proliferation; therefore, the protective effect of IgM may be exerted only in part via Clq [37]. There is a long history of the study of natural antibodies in atherosclerosis, and they are reactive with an epitope that is found on apoptotic cell surfaces, oxLDL and bacterial wall components. ApoE ${ }^{-/-}$mice develop high titres of anti-oxLDL antibody [38], and $\mathrm{LDLR}^{-/-}$mice have readily detectable anti-oxLDL IgM [39]; these antibodies block the uptake of oxLDL by CD36-positive macrophages.

Overall, triglycerides and total cholesterol in complement-deficient mice appear not to be different from controls on either an $\mathrm{ApoE}^{-/-}$or $\mathrm{LDLR}^{-/-}$background alone (which already present with hyperlipidaemia) with two exceptions; Bf-deficient $\left(\mathrm{Bf}^{-/}\right) / \mathrm{LDLR}^{-/-}$mice have significantly reduced cholesterol levels on an HFD compared with Bf-sufficient $\mathrm{LDLR}^{-/-}$mice [32], and $\mathrm{C}^{-/-} / \mathrm{ApoE}^{-/-}$ $\mathrm{LDLR}^{-/}$mice on normal chow show significantly increased levels of serum triglycerides and cholesterol compared to C3-sufficient ApoE ${ }^{-/-} / \mathrm{LDLR}^{-/-}$controls [33]. Although the postprandial clearance of triglycerides was the same between $\mathrm{C}^{-/-} / \mathrm{ApoE}^{-/-} / \mathrm{LDLR}^{-/-}$and $\mathrm{C} 3$-sufficient $\mathrm{ApoE}^{-/-} / \mathrm{LDLR}^{-/}$controls, $\mathrm{C}^{-/-} / \mathrm{ApoE}^{-/-} / \mathrm{LDLR}^{-/-}$ mice weighed significantly less than their $\mathrm{C} 3$-sufficient controls with a marked decrease in adipose tissue. Previous work using $\mathrm{C}^{-/-}$mice demonstrated that triglyceride and cholesterol levels in plasma in mice fed a normal diet were not altered in the absence of C3 [40], which is the precursor of $\mathrm{C} 3 \mathrm{a}^{\mathrm{des} A r g}$ (acylation stimulatory protein, ligand for C5L2, a stimulatory receptor for triglyceride synthesis), although postprandially they did demonstrate delayed triglyceride clearance $[41,42]$. This shows the importance of using atherosclerosis-prone mouse lines to investigate the pathogenesis of diet-induced atherosclerosis and of measuring relevant parameters. It also demonstrates that atherosclerotic phenotypes dependent on complement, such as C3 and Bf, may be markedly influenced by concomitant metabolic changes, such as hypoand hypercholesterolaemia, respectively.

Table 2 collates the measurements performed in models using the aforementioned transgenes for complement 
Table 1. Overview of in vivo studies investigating the contribution of complement to murine ApoE ${ }^{-/-}$and $\mathrm{LDLR}^{-/-}$phenotypes

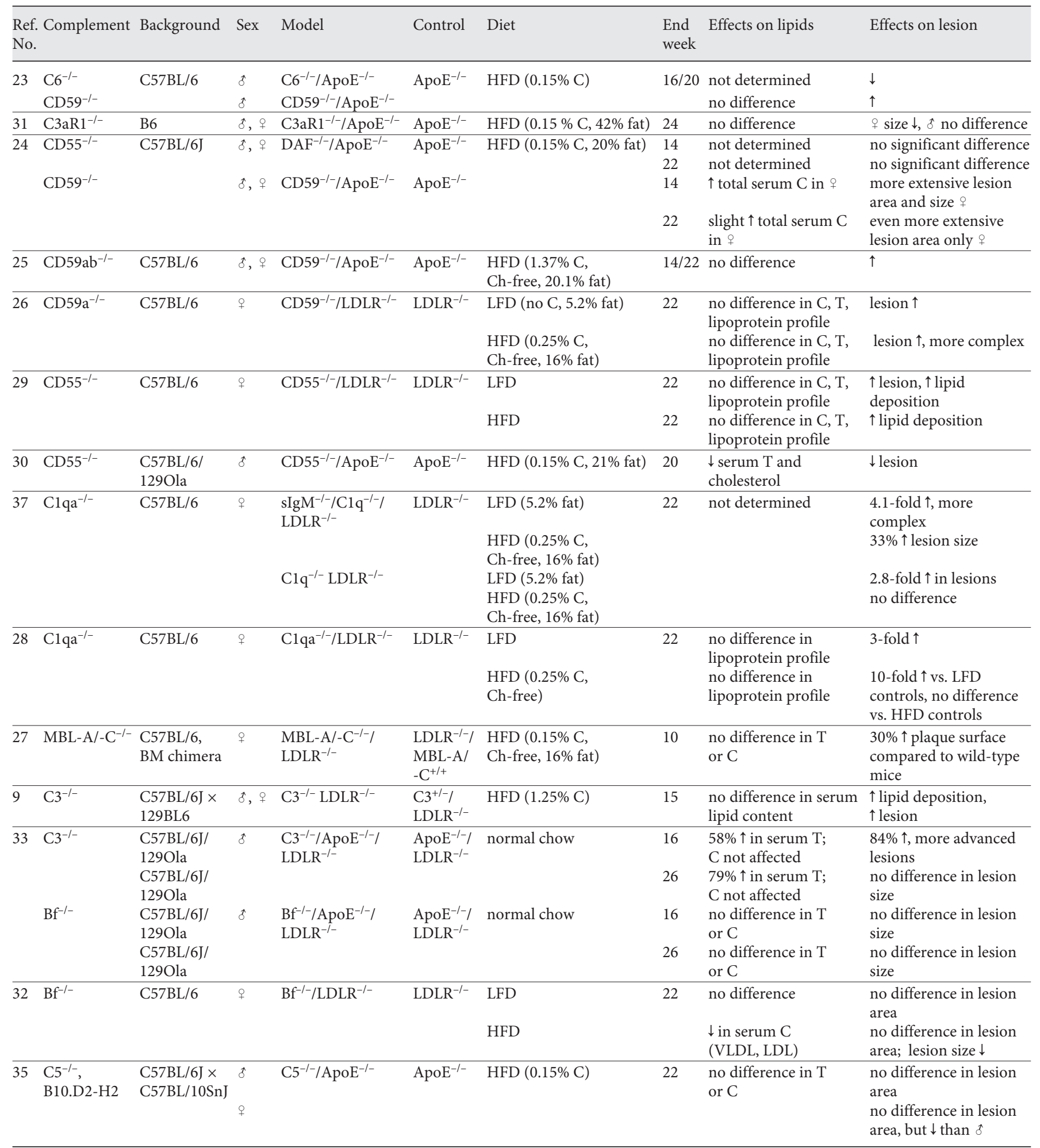

$\mathrm{T}=$ Triglycerides $\mathrm{C}=$ cholesterol; $\mathrm{Ch}=$ cholate (cholate facilitates fat and cholesterol absorption); LFD = low-fat diet; VLDL = very low-density lipoprotein; $\uparrow=$ increase; $\downarrow=$ decrease. 
Table 2. Methodological characterisations of the atherosclerotic phenotype in $\mathrm{ApoE}^{-/-}$and $\mathrm{LDLR}^{-/-}$models

\begin{tabular}{|c|c|c|}
\hline Descriptors & Method & Ref. No. \\
\hline \multicolumn{3}{|l|}{ Lesion size } \\
\hline \multicolumn{3}{|l|}{ Histological features } \\
\hline Aorta en face and/or staining by aortic root section & $\begin{array}{l}\text { Sudan IV/Oil Red O/Mayer } \\
\text { hematoxylin/TOPRO-3 }\end{array}$ & $\begin{array}{l}9,23,24,25,26,28,29, \\
31,32,33,37\end{array}$ \\
\hline Lipid content & Oil Red O & 28,35 \\
\hline Endothelial damage & Evans blue staining & 25 \\
\hline Collagen deposition & Picrosirius Red & $9,24,27,29$ \\
\hline Fibrosis, cholesterol clefts, acellular areas and fibrous cap & hematoxylin and eosin & 31,33 \\
\hline Foam cells & Oil Red O & 25 \\
\hline Elastin & Miller/Van Gieson & 25 \\
\hline \multicolumn{3}{|l|}{ Cellular and humoral characterisations } \\
\hline Complement deposition, binding & $\begin{array}{l}\text { C3, C3d, C9/MAC, C5, C5b-9, DAF, } \\
\text { CD } 59 \text { antibodies }\end{array}$ & $\begin{array}{l}9,23,25,26,29,31 \\
32,37\end{array}$ \\
\hline Macrophage content & CD68, MOMA-2, Mac3 antibodies & $23,25,26,31,32,33,37$ \\
\hline Vascular smooth muscle cell content & $\alpha$-smooth muscle actin antibody & $25,26,32,33,37$ \\
\hline T cell content & CD3, CD4 and CD8 antibodies & 25,37 \\
\hline Apoptotic cells & $\begin{array}{l}\text { anti-cleaved caspase } 3 \text { antibody, } \\
\text { terminal uridine nick-end labelling }\end{array}$ & $25,26,31,37$ \\
\hline B cell content & CD19 antibody & 26 \\
\hline IgG/IgM deposition & confocal microscopy & 37 \\
\hline Foam cells & CD11b antibody & 35 \\
\hline Triglyceride levels and clearance & enzymatic assays & 27,33 \\
\hline Complement activation: C3, C3a levels & ELISA & 29,32 \\
\hline Lipoprotein profile and cholesterol & $\begin{array}{l}\text { gel filtration liquid chromatography/ } \\
\text { enzymatic assay }\end{array}$ & $\begin{array}{l}9,23,25,29,32,33 \\
35,37\end{array}$ \\
\hline IgM and IgG levels, auto-antibodies for oxLDL/modified LDL & ELISA & $9,31,33$ \\
\hline ssDNA, dsDNA, chromatin, histone & ELISA & 28,37 \\
\hline Endothelial damage & ELISA (for vWF in serum) & 25 \\
\hline
\end{tabular}

proteins and $\mathrm{LDLR}^{-/-}$and/or ApoE ${ }^{-/-}$mice. Constituents of atherosclerotic lesions (lipids, collagen, monocytes and smooth muscle cells) are key parameters to characterise the atherosclerotic phenotype, but these analyses are not carried out in every study. A complex lesion is defined by an increase in smooth muscle cell and collagen content, a concomitant decrease in macrophages and the development of a fibrous cap. The quantification of atherosclerosis in mice involves two principal methods, en face (lesion area) and aortic root (lesion size), with en face measurement normally requiring higher cholesterol consumption [43]. Other common measurements relate to general physiological parameters (body weight, body fat, heartbody weight ratio).

Complement in Diet-Induced Murine

Atherosclerosis

\section{Procoagulant Activity and Complement in Atherosclerosis}

Platelets are essential in thrombus formation over dysfunctional and eroded or fissured atherosclerotic lesions and play an important role in the development and progression of atherosclerosis. Thrombosis is a response mechanism to vascular damage including, typically, the late stage of atherosclerotic plaque rupture. Endothelial cell injury induces platelet adhesion to the vessel wall and secretion of von Willebrand factor (vWF), which promotes platelet recruitment. A rise in vWF levels has been shown in $\mathrm{CD} 59 \mathrm{ab}^{-/-} / \mathrm{ApoE}^{-/-}$mice on an HFD, which demonstrate a high incidence of occlusive coronary atherosclerosis and mortality [25]. Interestingly, vWF was 
shown to co-purify with properdin, possibly interacting through its thrombospondin-like domains [44], but the relevance of this finding has not yet been studied in vivo. Platelet activation promotes activation of the coagulation cascade; oxLDL stimulates macrophage-mediated activation of the intrinsic coagulation pathway, and TF, important for the activation of the extrinsic coagulation pathway, is expressed in macrophages of atheromatous plaques [45]. Risk factors for the development of atherosclerosis, such as hypertension and dyslipidaemia, can elevate TF expression in atherosclerotic lesions and contribute to the thrombotic phenotype of disease, but the role of TF in murine atherogenesis models is still unclear [46]. Interestingly, C5a is a sufficient stimulus to induce expression of TF in endothelial cells [47] and therefore would appear to be relevant in inflammation-associated atherosclerosis. Apart from their role in progressive disease, platelets have also been shown to adhere to endothelial cells in $\mathrm{ApoE}^{-/-}$mice before lesion development [48]. Platelet microparticles, membranous vesicles released from activated platelets, provide surfaces which are conducive to complement activation via $\mathrm{CP}$ and $\mathrm{AP}$, even in the presence of membrane-bound regulators of complement activation [49]. Platelet microparticles express P-selectin, which binds $\mathrm{C} 3 \mathrm{~b}$ and supports Bf-dependent complement activation (AP) [50]. Importantly, platelet microparticles are detectable in mice and are thought to facilitate adhesion of monocytes to inflamed endothelium, leading to the formation of foam cells, but have not yet been studied in the existing compound complement/ LDLR/ApoE-deficient mouse models.

\section{Adipose Tissue Produces Complement Factors and Sustains Inflammation That Aggravates Atherosclerosis}

Aside from being a lipid storage organ, adipose tissue is an endocrine organ active in the secretion of a variety of adipokines. The extent of its contribution to systemic immunity and inflammation has not yet been quantified, though expression of pro-inflammatory genes [e.g. interleukin (IL)-6 and monocyte chemoattractant protein (MCP)-1] and plasticity within the tissue have been documented. Adipocytes express a pattern of Toll-like receptors (TLRs) which depends on their state of differentiation, meaning that a different response to inflammation is exhibited by pre-adipocytes and mature adipocytes. Adipose tissue is seen as an immune responsive organ based on TLR signalling and secretion of inflammatory markers such as cytokines, growth factors and also complement components (factors B, D and C3) [51]. The exact cellular origin of these mediators, including complement proteins, from within the adipose tissue remains an issue of debate. While there is certainty regarding the capacity of adipocytes to act as immune cells [52], it has been reported that separation of cells from murine white adipose tissue produces lipid-rich floating adipocytes and a fraction containing stroma-vascular cells, a mixture of preadipocytes, endothelial cells and various immune cells [53]. Expression of inflammation genes [tumor necrosis factor (TNF) $-\alpha$, macrophage inflammatory protein $-1 \alpha$ and $\mathrm{MCP}-1]$ was found in the $\mathrm{Mac}-1^{+} / \mathrm{F} 4 / 80^{+} / \mathrm{CD} 68^{+}$stroma-vascular fraction but not the leptin-positive adipocyte fraction [53]. A study investigating the production of adipokines from human adipose explants (containing adipocytes and stroma-vascular cells) and from isolated adipocytes in parallel found that adipokines such as IL-8, IL-6, vascular endothelial growth factor and TNF- $\alpha$ (but not adiponectin and leptin) are produced by non-fat cells (present in adipose tissue explants but not in adipocyte cultures) [54]. Therefore, studies investigating gene expression of the entire tissue, comprising a mixture of adipocytes, pre-adipocytes, macrophages, mast cells and endothelial cells, may provide a more useful insight into the potential of cells within the adipose context to modulate systemic disease [55]. In our hands, methodological variability, especially the duration of collagenase digestion, accounted for varying purity of the adipose and stroma-vascular subpopulations prepared from mouse epididymal adipose tissue.

Nevertheless, it is clear that adipokines directly influence endothelial function, platelets and monocytes [56] and for this reason are underestimated modulators of systemic inflammation, together with adipose tissue-resident macrophages, which express a phenotype (M2 type) determined by the adipose environment [57]. Adipose tissue-derived leptin, adiponectin and IL- 6 have a direct role in endothelial dysfunction and platelet activation [58]. Adiponectin is protective against early atherosclerosis by suppressing the production of adhesion molecules and cytokines (e.g. TNF- $\alpha$ ) from endothelial cells and macrophages, respectively. It also binds $\mathrm{Clq}$ and factor $\mathrm{H}$ (inhibitor of C3 and C5 convertases of the AP of complement activation), leading to a less pro-inflammatory engagement of complement activation [59]. Mast cell-derived cytokines are integral modulators of white adipose tissue and energy expenditure [60]. Adipose tissue-resident mast cells express complement properdin [61], but its importance in the generation of $\mathrm{C} 3 \mathrm{a}^{\text {desArg }}$ as well as in 
sustaining the inflammatory capacity of adipose tissue has not yet been investigated. Adipsin, a serine protease identical to human complement factor $\mathrm{D}$, is produced by adipose tissue and secreted into the blood; genetically obese rats and mice show a substantial reduction of adipsin mRNA in their adipose tissue [62].

A role for perivascular adipose tissue in the pathogenesis of atherosclerosis was proposed based on its chemoattractive capacity [63]. Since then, studies have concluded that coronary perivascular adipose tissue is related to coronary artery disease in humans but also that perivascular adipose tissue in mice is composed of white as well as brown fat with regional differences (thoracic vs. abdominal aorta) and plasticity on an HFD [64]. Adipose tissue, macrophages and mast cells in periarterial locations all contribute to thrombogenicity and plaque progression.

\section{Macrophages Express Complement Factors and Are Pathogenic in Vessel Wall and Adipose Tissue}

Monocytes adhere to endothelial cells and infiltrate the arterial intima where they mature into macrophages and internalise modified LDL to become foam cells, characterising early arteriosclerotic lesions. oxLDL acts as endogenous ligand for signalling via TLR2 and TLR4, resulting in the release of pro-inflammatory TNF- $\alpha$ by macrophages [65]. Advanced atherosclerotic lesions exhibit hypoxic areas; accumulating macrophages respond to hypoxia by up-regulating a number of genes required for angiogenesis and cell survival. Plaque destabilisation is brought about not only by matrix metalloproteinase (MMP)-expressing macrophages but also by mast cells. The levels and activity of MMP-1 and MMP-9 in human monocyte-derived macrophages were increased in vitro by the anaphylatoxin $\mathrm{C} 5 \mathrm{a}$, and $\mathrm{C} 5 \mathrm{a}$ as well as MMP-1 and MMP-9 were found to be co-expressed in human atherectomy specimens [66].

Macrophages express most complement components and receptors but are a heterogenous and dynamic cell group characterised by differential expression of markers, which are not uniformly used in immunohistochemical analyses of lesion material.

In aortas of $\mathrm{ApoE}^{-/-}$mice (fed normal chow), significantly more $\mathrm{F} 4 / 80^{+} / \mathrm{C}^{2} \mathrm{aR}^{+}$macrophages were observed at 25 weeks of age compared to wild-type controls (C57BL/6J). Administration of the C5a antagonist PMX53 from 5 to 30 weeks of age led to a significant reduction in lipid area and size in this treated group compared to the untreated $\mathrm{ApoE}^{-/-}$group, though the treatment did not alter the lesional content of $\mathrm{CD} 68^{+}$macrophages [67]. By contrast, in the absence of C1q or CD55, HFD-fed $\mathrm{LDLR}^{-/}$mice showed fewer lesional MOMA-2 ${ }^{+}$macrophages compared to $\mathrm{LDLR}^{-/-}$controls $[28,29]$, and the content of $\mathrm{Mac}^{-} 3^{+}\left(\mathrm{LAMP}-2^{+}\right)$macrophages was higher in HFD-fed C3 ${ }^{-/-} / \mathrm{LDLR}^{-/-}$mice compared to $\mathrm{LDLR}^{-/-}$controls [9]. These changes relate to the increased severity of the lesion phenotype in each of these compound complement/LDLR-deficient models.

Macrophage migration inhibitory factor (MIF) is a pro-inflammatory cytokine which attracts macrophages to adipose tissue in $\mathrm{LDLR}^{-/-}$mice [68]; its significance in disease progression was deduced from studies investigating $\mathrm{MIF}^{-/-} / \mathrm{LDLR}^{-/-}$mice on normal chow over 52 weeks, which showed a significant reduction in the atherosclerotic lesion area compared to $\mathrm{LDLR}^{-1-}$ controls [68]. In HFD-fed mice, the number of macrophages in adipose tissue is increased, and they contribute to the increase in $\mathrm{C} 3 \mathrm{aR}$ expression as described elsewhere [69]. There is a greater increase in pro-inflammatory $\mathrm{CD}_{11 \mathrm{c}^{+}}$M1-type macrophages (secretion of inducible nitric oxide synthase and TNF- $\alpha$ ) than CD206 ${ }^{+}$M2-type macrophages (involved in tissue remodelling via secretion of MMPs) in epididymal fat tissue [70], but this shift may critically depend on the caloric value of the HFD [71]. How complement activation-derived factors are involved in the process of macrophage and immune cell recruitment to adipose tissue during the development of obesity is an area that remains to be explored, although it is clear that the proximal complement pathway (and production of $\mathrm{C} 3 \mathrm{a}^{\mathrm{des} A r g}$ ) is functional, with demonstration of increases in C3a ${ }^{\text {desArg }}$ production in HFD-fed mice [72].

The importance of M1- and M2-type macrophages in relation to the development of murine atheromatous plaques has been investigated in models using M1/M2 ex vivo polarised bone marrow-derived macrophages and $\mathrm{ApoE}^{-/-}$mice. Of greater immediate relevance, however, are perivascular macrophages which, via TNF- $\alpha$ secretion, may activate vascular smooth muscle cells to express a phenotype consistent with lymphoid tissue organising cells [73]. This is important because tertiary lymphoid organs are local immune environments, which lead to perpetuation of any chronic inflammatory disease.

$\mathrm{F}_{c} \gamma$ receptors $\left(\mathrm{F}_{\mathrm{c}} \gamma \mathrm{Rs}\right)$ are IgG-binding receptors expressed by myeloid cells, which trigger cellular responses such as macrophage phagocytosis and endothelial dysfunction [74]. $F_{c} \gamma$ RIIB inhibits the development of atherosclerosis in $\mathrm{LDLR}^{-/-}$mice, even when fed a diet of $0.15 \%$ cholesterol and $21 \%$ fat [75]. Although cooperation 
between $\mathrm{F}_{\mathrm{c}} \gamma \mathrm{Rs}$ and complement has been described [76, 77], this has not yet been studied for atherosclerosis, even though anti-oxLDL antibodies are present and macrophage activation is a hallmark in the development of plaques. IL-1, IL-12, IL-18, MIF, TNF- $\alpha$, interferon- $\gamma$ and macrophage colony-stimulating factor are pro-atherogenic cytokines, as deduced from a wealth of mouse models. Unfortunately, their levels have not been studied in the complement-deficient mouse models, which are increasingly being used to identify a role of complement regulation and activation in the process of atheromatous plaque development. In this context, IL-12 seems of particular interest; it is produced by adipocytes during inflammation, it is one of the key drivers in Th1-dominated development of atheromatous lesions, and complement activation leads to an increase in IL-12 production via macrophage-expressed complement receptor CR3 and release of complement C5a $[78,79]$.

\section{Perspective}

Using genetically engineered mice, evidence for the differential involvement of complement in progressive atherogenic inflammation has been provided. Many questions remain. One limitation, as can be seen from the compilation of studies in table 1 , is the variety of backgrounds, use of male or female mice, feeding protocols and the scope of measurements. To maximise the knowledge gained through these laborious in vivo studies, consensus in the community on the choice of protocol would be desirable. Further frontiers remain; no model yet has addressed the role of infection, platelet function or adipose tissue together with complement in the context of atherosclerotic disease. Because complement has humoral as well as cellular effects, acting systemically as well as locally (fig. 2), the dissection of its role in complex, nonacute disease such as atherosclerosis is bound to be difficult, in spite of the availability of specific gene-targeted experimental mice.

As part of the normal recognition of patterns, the complement system and the TLR-mediated response have so far been investigated singly in order to ascertain their individual roles and importance within innate immune defence. More recently, the implications of the overlap in activation of these two pattern-effector systems have begun to be investigated. Joint activation of complement and TLR leading to a cellular response which, driven by IL-6, develops into a Th17-driven phenotype [80], is likely to play a role in atherosclerosis mod-

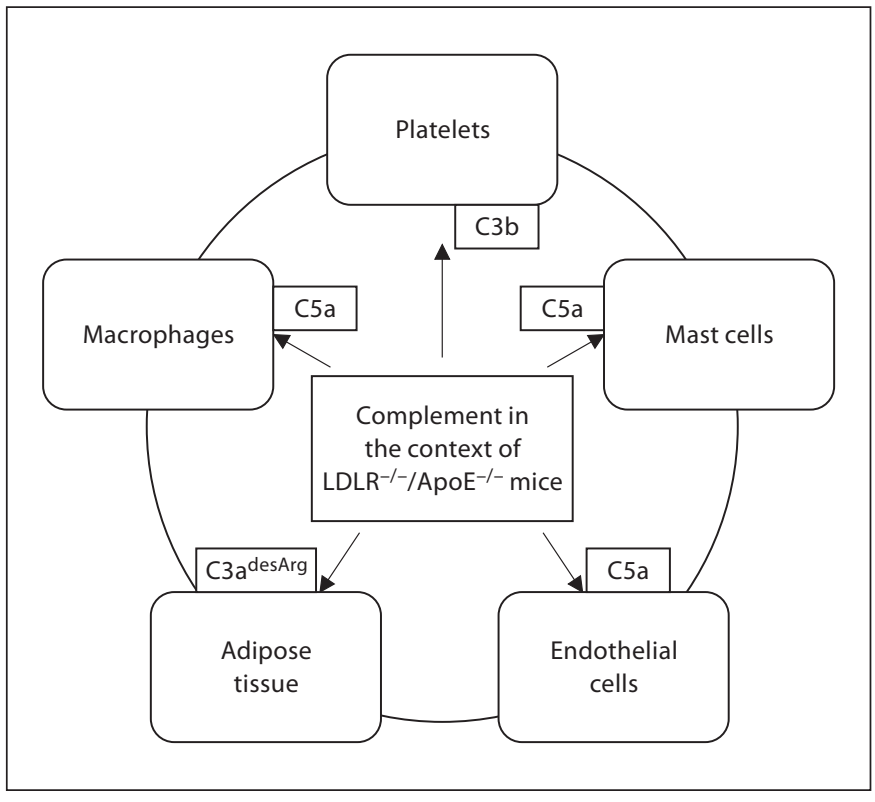

Fig. 2. Complement - an agent in activation of cells and intercellular communication.

els incorporating an infectious precipitant. IL-17 was found to be significantly elevated in the walls of atherosclerotic vessels of HFD-fed $\mathrm{ApoE}^{-/-}$mice by immunohistochemistry and RT-PCR. Further, $\mathrm{CD} 4^{+} / \mathrm{IL}-17^{+} /$interferon- $\gamma^{+}$(Th1/Th17) $\mathrm{T}$ cells were elevated in the spleens of HFD-fed ApoE ${ }^{-/-}$mice at the late stage, and their numbers correlated with the plaque area [81]. Therefore, it will be of interest in future to follow the modulation of this cellular phenotype in complement-deficient experimental mouse models of atherosclerosis.

Current therapeutics target risk factors for cardiovascular events, which are associated with atherosclerosis, such as platelet aggregation and elevated cholesterol and triglyceride levels [5]. Since its discovery as a targetable, significant mediator of mortality due to sepsis, inhibition of C5a-mediated signalling has been pursued in pre-clinical and clinical trials [82]. A C5a antagonist was not found to reverse the complexity of atherosclerotic histopathology; rather it significantly reduced plaque lipid areas [83]. Others see an application of complement activation inhibitors in the acute phases of chronic disease [84]. The aim of the experimental mouse model work is to identify complement factors which, if significantly important in the pathogenesis of disease, could be targeted in order to interfere with the natural progression of atheroma development. However, mechanisms by which these individual factors exert their significant actions are 


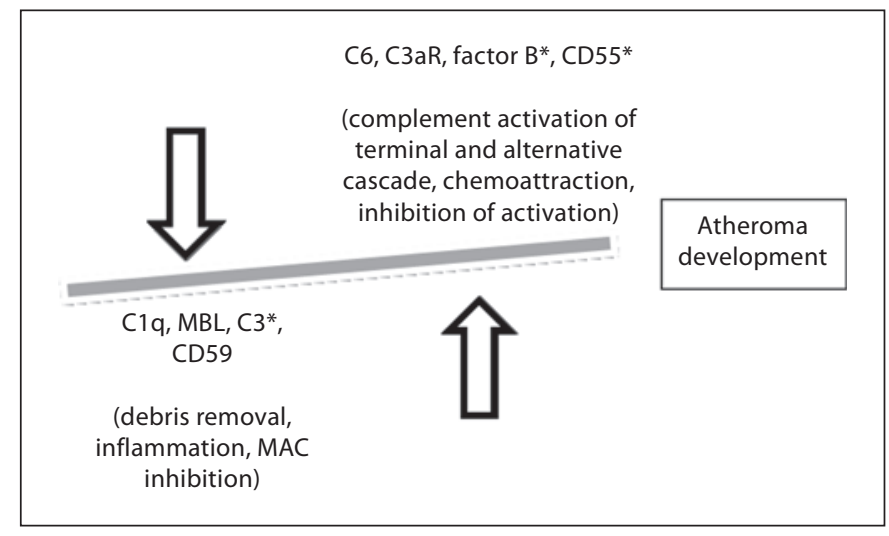

Fig. 3. Complement - a balancing act. * Effects on lipid metabolism as deduced from the use of gene-targeted mice: factor $\mathrm{B}$ and C3 in LDLR ${ }^{-/}$mice have antagonistic effects on lipids; while the former raises cholesterol levels, the latter lowers triglycerides. CD55 in $\mathrm{LDLR}^{-/-}$mice leads to elevated triglyceride and cholesterol levels.

not yet clear (fig. 3). Assessing the contribution of complement by investigating complement-deficient mice at a protracted endpoint may miss these important temporal factors; the effect of complement might well be to sustain the pathologic process over time, but complement may also have a more instructive role early on in disease development (such as M1/2 biasing [85]). Alternatively, as the disease progresses, there may be a qualitative change in the involvement of complement, such as when shear stress of endothelial cells (relevant in areas of plaque formation) increases properdin expression [86].

So far, complement has been viewed in a mainly proinflammatory capacity; its relevance in lipid metabolism is only beginning to be investigated more thoroughly. In fact, its role in atheroprotection/atherogenesis may operate via regulation of lipid metabolism; the most recent findings using a $\mathrm{CD} 55^{-/-} / \mathrm{ApoE}^{-/-}$model suggest that C3a $\mathrm{a}^{\text {desArg }}$ levels may provide the missing link between diet, blood biochemistry and vascular changes [30].

The approach, namely to dissect into small parts those components which we seek to understand in detail, to then put together as a greater whole, i.e. to synthesise, in order to gain fuller understanding of the experiments and reality, reminds us of the Cartesian method of science. It is becoming clear that in order for this process to be meaningful physiologically, present avenues in atherosclerosis research need to be extended to include, for example, the role of complement in adipose tissue enhanced platelet/leukocyte aggregates (a connection between the latter two entities has been made [87]) as well as the role of complement in the interactions between renal failure and adipose tissue [88]. Great advances are to be expected from a multidisciplinary approach.

\section{Acknowledgements}

This project (complement/atherosclerosis) is supported by the British Heart Foundation (grant number PG/09/053/27836, awarded to C.S. and S.F.). Katherine Cianflone is a Canada Research Chair Scholar. We acknowledge Professor Alison Goodall (University of Leicester) for helpful discussions.

\section{Disclosure Statement}

There is no conflict of interest.

\section{References}

1 Staprans I, Pan XM, Rapp JH, Grunfeld C Feingold KR: Oxidized cholesterol in the diet accelerates the development of atherosclerosis in LDL receptor- and apolipoprotein Edeficient mice. Arterioscler Thromb Vasc Biol 2000;20:708-714.

$\checkmark 2$ Horie S, Hiraishi S, Hirata Y, Kazama M, Matsuda J: Oxidized low-density lipoprotein impairs the anti-coagulant function of tissuefactor-pathway inhibitor through oxidative modification by its high association and accelerated degradation in cultured human endothelial cells. Biochem J 2000;352:277-285.
3 Baigent C, Keech A, Kearney PM, Blackwell L, Buck G, Pollicino C, Kirby A, Sourjina T, Peto R, Collins R, Simes R; Cholesterol Treatment Trialists' (CTT) Collaborators: Efficacy and safety of cholesterol-lowering treatment: prospective meta-analysis of data from 90,056 participants in 14 randomised trials of statins. Lancet 2005;366:1267-1278.

-4 Ko YG, Kim BK, Lee BK, Kang WC, Choi SH, Kim SW, Lee JH, Lee M, Honda Y, Fitzerald PJ, Shim WH; SECURE Investigators: Study design and rationale of 'Synergistic effect of combination therapy with cilostazol and ProbUcol on plaque stabilization and lesion REgression (SECURE)' study: a doubleblind randomised controlled multicenter clinical trial. Trials 2011;12:10.
5 Koenen RR, Weber C: Therapeutic targeting of chemokine interactions in atherosclerosis. Nat Rev Drug Discov 2010;9:141-153.

-6 Ricklin D, Hajishengallis G, Yang K, Lambris JD: Complement: a key system for immune surveillance and homeostasis. Nat Immunol 2010;11:785-797.

-7 Alving CR, Richards RL, Guirguis AA: Cholesterol-dependent human complement activation resulting in damage to liposomal model membranes. J Immunol 1977;118: 342-347. 
$>8$ Seifert PS, Hugo F, Tranum-Jensen J, Zâhringer U, Muhly M, Bhakdi S: Isolation and characterization of a complement-activating lipid extracted from human atherosclerotic lesions. J Exp Med 1990;172:547557.

$>9$ Buono C, Come CE, Witztum JL, Maguire GF, Connelly PW, Carroll M, Lichtman AH: Influence of C3 deficiency on atherosclerosis. Circulation 2002;105:3025-3031.

-10 Thorbjornsdottir P, Kolka R, Gunnarsson E, Bambir SH, Thorgeirsson G, Kotwal GJ, Arason GJ: Vaccinia virus complement control protein diminishes formation of atherosclerotic lesions: complement is centrally involved in atherosclerotic disease. Ann NY Acad Sci 2005;1056:1-15.

11 Jha P, Kotwal GJ: Vaccinia complement control protein: multi-functional protein and a potential wonder drug. J Biosci 2003;28:265271.

12 Knowles JW, Maeda N: Genetic modifiers of atherosclerosis in mice. Arterioscler Thromb Vasc Biol 2000;20:2336-2345.

13 Getz GS, Reardon CA: Diet and murine atherosclerosis. Arterioscler Thromb Vasc Biol 2006;26:242-249.

14 Plump AS, Smith JD, Hayek T, Aalto-Setälä K, Walsh A, Verstuyft JG, Rubin EM, Breslow JL: Severe hypercholesterolemia and atherosclerosis in apolipoprotein E-deficient mice created by homologous recombination in ES cells. Cell 1992;71:343-353.

- 15 Zadelaar S, Kleemann R, Verschuren L, de Vries-Van der Weij J, van der Hoorn J, Princen HM, Kooistra T: Mouse models for atherosclerosis and pharmaceutical modifiers. Arterioscler Thromb Vasc Biol 2007;27: 1706-1721.

-16 Ishibashi S, Brown MS, Goldstein JL, Gerard RD, Hammer RE, Herz J: Hypercholesterolemia in low density lipoprotein receptor knockout mice and its reversal by adenovirus-mediated gene delivery. J Clin Invest 1993;92:883-893

$\checkmark 17$ Williams H, Johnson JL, Carson KG, Jackson CL: Characteristics of intact and ruptured atherosclerotic plaques in brachiocephalic arteries of apolipoprotein E knockout mice. Arterioscler Thromb Vasc Biol 2002;22:788792.

18 Virella G, Lopes-Virella MF: Infections and atherosclerosis. Transplant Proc 1987;19(4 suppl 5):26-35.

19 Grayston JT: Chlamydia in atherosclerosis. Circulation 1993;87:1408-1409.

20 Deniset JF, Pierce GN: Possibilities for therapeutic interventions in disrupting Chlamydophila pneumoniae involvement in atherosclerosis. Fundam Clin Pharmacol 2010 24:607-617.
Kleemann R, Verschuren L, van Erk MJ, Nikolsky Y, Cnubben NH, Verheij ER, Smilde AK, Hendriks HF, Zadelaar S, Smith GJ, Kaznacheev V, Nikolskaya T, Melnikov A, Hurt-Camejo E, van der Greef J, van Ommen B, Kooistra T: Atherosclerosis and liver inflammation induced by increased dietary cholesterol intake: a combined transcriptomics and metabolomics analysis. Genome Biol 2007;8:R200.

22 Recinos A 3rd, Carr BK, Bartos DB, Boldogh I, Carmical JR, Belalcazar LM, Brasier AR: Liver gene expression associated with diet and lesion development in atherosclerosisprone mice: induction of components of alternative complement pathway. Physiol Genomics 2004;19:131-142.

23 Lewis RD, Jackson CL, Morgan BP, Hughes TR: The membrane attack complex of complement drives the progression of atherosclerosis in apolipoprotein $\mathrm{E}$ knockout mice. Mol Immunol 2010;47:1098-1105.

24 An G, Miwa T, Song WL, Lawson JA, Rader DJ, Zhang Y, Song WC: CD59 but not DAF deficiency accelerates atherosclerosis in female ApoE knockout mice. Mol Immunol 2009;46:1702-1709.

25 Wu G, Hu W, Shahsafaei A, Song W, Dobarro $M$, Sukhova GK, Bronson RR, Shi GP, Rother RP, Halperin JA, Qin X: Complement regulator CD59 protects against atherosclerosis by restricting the formation of complement membrane attack complex. Circ Res 2009; 104:550-558.

26 Yun S, Leung VW, Botto M, Boyle JJ, Haskard DO: Brief report: accelerated atherosclerosis in low-density lipoprotein receptordeficient mice lacking the membrane-bound complement regulator CD59. Arterioscler Thromb Vasc Biol 2008;28:1714-1716.

27 Matthijsen RA, de Winther MP, Kuipers D, van der Made I, Weber C, Herias MV, Gijbels MJ, Buurman WA: Macrophage-specific expression of mannose-binding lectin controls atherosclerosis in low-density lipoprotein receptor-deficient mice. Circulation 2009; 119:2188-2195.

28 Bhatia VK, Yun S, Leung V, Grimsditch DC, Benson GM, Botto MB, Boyle JJ, Haskard DO: Complement $\mathrm{Clq}$ reduces early atherosclerosis in low-density lipoprotein receptordeficient mice. Am J Pathol 2007;170:416426.

29 Leung VW, Yun S, Botto M, Mason JC, Malik $\mathrm{TH}$, Song W, Paixao-Cavalcante D, Pickering MC, Boyle JJ, Haskard DO: Decay-accelerating factor suppresses complement $\mathrm{C} 3 \mathrm{ac}$ tivation and retards atherosclerosis in low density lipoprotein receptor-deficient mice. Am J Pathol 2009;175:1757-1767.

30 Lewis RD, Perry MJ, Guschina IA, Jackson CL, Morgan BP, Hughes TR: CD55 deficiency protects against atherosclerosis in ApoE deficient mice via C3a modulation of lipid metabolism. Am J Pathol 2011;179:16011607.
1 Yang X, Peterson L, Thieringer R, Deignan JL, Wang X, Zhu J, Wang S, Zhong H, Stepaniants S, Beaulaurier J, Wang IM, Rosa R, Cumiskey AM, Luo JM, Luo Q, Shah K, Xiao J, Nickle D, Plump A, Schadt EE, Lusis AJ, Lum PY: Identification and validation of genes affecting aortic lesions in mice. J Clin Invest 2010;120:2414-2422.

32 Malik TH, Cortini A, Carassiti D, Boyle JJ, Haskard DO, Botto M: The alternative pathway is critical for pathogenic complement activation in endotoxin- and diet-induced atherosclerosis in low-density lipoprotein receptor-deficient mice. Circulation 2010; 122:1948-1956.

33 Persson L, Borén J, Robertson AK, Wallenius V, Hansson GK, Pekna M: Lack of complement factor $\mathrm{C} 3$, but not factor $\mathrm{B}$, increases hyperlipidemia and atherosclerosis in apolipoprotein E-/- low-density lipoprotein receptor-/- mice. Arterioscler Thromb Vasc Biol 2004;24:1062-1067.

34 Speidl WS, Kastl SP, Huber K, Wojta J: Complement in atherosclerosis - friend or foe? J Thromb Haemost 2011;9:428-440.

35 Patel S, Thelander EM, Hernandez M, Montenegro J, Hassing $\mathrm{H}$, Burton $\mathrm{C}$, Mundt $\mathrm{S}$, Hermanowski-Vosatka A, Wright SD, Chao YS, Detmers PA: ApoE(-/-) mice develop atherosclerosis in the absence of complement component C5. Biochem Biophys Res Commun 2001;286:164-170.

-36 Chou MY, Fogelstrand L, Hartvigsen K, Hansen LF, Woelkers D, Shaw PX, Choi J, Perkmann T, Bäckhed F, Miller YI, Hörkkö S, Corr M, Witztum JL, Binder CJ: Oxidation-specific epitopes are dominant targets of innate natural antibodies in mice and humans. J Clin Invest 2009;119:1335-1349.

-37 Lewis MJ, Malik TH, Ehrenstein MR, Boyle JJ, Botto M, Haskard DO: Immunoglobulin $\mathrm{M}$ is required for protection against atherosclerosis in low-density lipoprotein receptordeficient mice. Circulation 2009;120:417426.

38 Shaw PX, Hörkkö S, Chang MK, Curtiss LK, Palinski W, Silverman GJ, Witztum JL: Natural antibodies with the T15 idiotype may act in atherosclerosis, apoptotic clearance, and protective immunity. J Clin Invest 2000; 105:1731-1740.

-39 Stanic AK, Stein CM, Morgan AC, Fazio S, Linton MF, Wakeland EK, Olsen NJ, Major AS: Immune dysregulation accelerates atherosclerosis and modulates plaque composition in systemic lupus erythematosus. Proc Natl Acad Sci USA 2006;103:7018-7023.

40 Wetsel RA, Kildsgaard J, Zsigmond E, Liao W, Chan L: Genetic deficiency of acylation stimulating protein (ASP(C3ades-Arg)) does not cause hyperapobetalipoproteinemia in mice. J Biol Chem 1999;274:19429-19433.

41 Murray I, Sniderman AD, Cianflone K: Mice lacking acylation stimulating protein (ASP) have delayed postprandial triglyceride clearance. J Lipid Res 1999;40:1671-1676. 
$\checkmark 42$ Murray I, Sniderman AD, Havel PJ, Cianflone K: Acylation stimulating protein (ASP) deficiency alters postprandial and adipose tissue metabolism in male mice. J Biol Chem 1999;274:36219-36225.

-43 Teupser D, Persky AD, Breslow JL: Induction of atherosclerosis by low-fat, semisynthetic diets in LDL receptor-deficient C57BL/6 and $\mathrm{FVB} / \mathrm{NJ}$ mice: comparison of lesions of the aortic root, brachiocephalic artery, and whole aorta (en face measurement). Arterioscler Thromb Vasc Biol 2003;23:1907-1913.

-44 Bjerketorp J, Nilsson M, Ljungh A, Flock JI, Jacobsson K, Frykberg L: A novel von Willebrand factor binding protein expressed by Staphylococcus aureus. Microbiology 2002; 148:2037-2044.

-45 Ananyeva NM, Kouiavskaia DV, Shima M, Saenko EL: Intrinsic pathway of blood coagulation contributes to thrombogenicity of atherosclerotic plaque. Blood 2002;99:44754485.

-46 Breitenstein A, Tanner FC, Luscher TF: Tissue factor and cardiovascular disease: quo vadis? Circ J 2010;74:3-12.

47 Ikeda K, Nagasawa K, Horiuchi T, Tsuru T, Nishizaka $\mathrm{H}$, Niho Y: C5a induces tissue factor activity on endothelial cells. Thromb Haemost 1997;77:394-398.

48 Massberg S, Brand K, Grüner S, Page S, Müller E, Müller I, Bergmeier W, Richter T, Lorenz M, Konrad I, Nieswandt B, Gawaz M: A critical role of platelet adhesion in the initiation of atherosclerotic lesion formation. J Exp Med 2002;196:887-896.

49 Yin W, Ghebrehiwet B, Peerschke EI: Expression of complement components and inhibitors on platelet microparticles. Platelets 2008; 19:225-233.

50 Del Conde I, Crúz MA, Zhang H, López JA, Afshar-Kharghan V: Platelet activation leads to activation and propagation of the complement system. J Exp Med 2005;201:871-879.

$\checkmark 51$ Berg AH, Scherer PE: Adipose tissue, inflammation, and cardiovascular disease. Circ Res 2005;96:939-949.

-52 Alexaki VI, Notas G, Pelekanou V, Kampa M, Valkanou M, Theodoropoulos P, Stathopoulos EN, Tsapis A, Castanas E: Adipocytes as immune cells: differential expression of TWEAK, BAFF, and APRIL and their receptors (Fn14, BAFF-R, TACI, and BCMA) at different stages of normal and pathological adipose tissue development. J Immunol 2009;183:5948-5956.

- 53 Xu H, Barnes GT, Yang Q, Tan G, Yang D, Chou CJ, Sole J, Nichols A, Ross JS, Tartaglia LA, Chen H: Chronic inflammation in fat plays a crucial role in the development of obesity-related insulin resistance. J Clin Invest 2003;112:1821-1830.
54 Fain JN, Madan AK, Hiler ML, Cheema P, Bahouth SW: Comparison of the release of adipokines by adipose tissue, adipose tissue matrix, and adipocytes from visceral and subcutaneous abdominal adipose tissues of obese humans. Endocrinology 2004;145: 2273-2282.

55 MacLaren RE, Cui W, Lu H, Simard S, Cianflone K: Association of adipocyte genes with ASP expression: a microarray analysis of subcutaneous and omental adipose tissue in morbidly obese subjects. BMC Med Genomics 2010;3:3.

56 Kougias P, Chai H, Lin PH, Yao Q, Lumsden $\mathrm{AB}$, Chen C: Effects of adipocyte-derived cytokines on endothelial functions: implication of vascular disease. J Surg Res 2005;126: 121-129.

57 Spencer M, Yao-Borengasser A, Unal R, Rasouli N, Gurley CM, Zhu B, Peterson CA, Kern PA: Adipose tissue macrophages in insulin resistant subjects are associated with collagen VI, fibrosis and demonstrate alternative activation. Am J Physiol Endocrinol Metab 2010;299:E1016-E1027.

58 Chudek J, Wiecek A: Adipose tissue, inflammation and endothelial dysfunction. Pharmacol Rep 2006;58(suppl):81-88.

59 Peake P, Shen Y: Factor H binds to the Nterminus of adiponectin and modulates complement activation. Biochem Biophys Res Commun 2010;397:361-366.

60 Liu J, Divoux A, Sun J, Zhang J, Clément K, Glickman JN, Sukhova GK, Wolters PJ, Du J, Gorgun CZ, Doria A, Libby P, Blumberg RS, Kahn BB, Hotamisligil GS, Shi GP: Genetic deficiency and pharmacological stabilization of mast cells reduce diet-induced obesity and diabetes in mice. Nat Med 2009;15:940945.

61 Pattrick M, Luckett J, Yue L, Stover C: Dual role of complement in adipose tissue. Mol Immunol 2009;46:755-760.

62 Platt KA, Min HY, Ross SR, Spiegelman BM: Obesity-linked regulation of the adipsin gene promoter in transgenic mice. Proc Natl Acad Sci USA 1989;86:7490-7494.

63 Henrichot E, Juge-Aubry CE, Pernin A, Pache JC, Velebit V, Dayer JM, Meda P, Chizzolini C, Meier CA: Production of chemokines by perivascular adipose tissue: a role in the pathogenesis of atherosclerosis? Arterioscler Thromb Vasc Biol 2005;25:2594-2599.

64 Police SB, Thatcher SE, Charnigo R, Daugherty A, Cassis LA: Obesity promotes inflammation in periaortic adipose tissue and angiotensin II-induced abdominal aortic aneurysm formation. Arterioscler Thromb Vasc Biol 2009;29:1458-1464.

65 Chavez-Sanchez L, Madrid-Miller A, Chávez-Rueda K, Legorreta-Haquet MV, Tesoro-Cruz E, Blanco-Favela F: Activation of TLR2 and TLR4 by minimally modified low-density lipoprotein in human macrophages and monocytes triggers the inflammatory response. Hum Immunol 2010;71: 737-744.
66 Speidl WS, Kastl SP, Hutter R, Katsaros KM, Kaun C, Bauriedel G, Maurer G, Huber K, Badimon JJ, Wojta J: The complement component $\mathrm{C} 5 \mathrm{a}$ is present in human coronary lesions in vivo and induces the expression of MMP-1 and MMP-9 in human macrophages in vitro. FASEB J 2011;25:35-44.

67 Manthey HD, Woodruff TM, Taylor SM, Monk PN: Complement component 5a (C5a). Int J Biochem Cell Biol 2009;41:21142117.

-68 Verschuren L, Kooistra T, Bernhagen J, Voshol PJ, Ouwens DM, van Erk M, de Vriesvan der Weij J, Leng L, van Bockel JH, van Dijk KW, Fingerle-Rowson G, Bucala R, Kleemann R: MIF deficiency reduces chronic inflammation in white adipose tissue and impairs the development of insulin resistance, glucose intolerance, and associated atherosclerotic disease. Circ Res 2009; 105: 99-107.

69 Mamane Y, Chung Chan C, Lavallee G, Morin N, Xu LJ, Huang J, Gordon R, Thomas W, Lamb J, Schadt EE, Kennedy BP, Mancini JA: The C3a anaphylatoxin receptor is a key mediator of insulin resistance and functions by modulating adipose tissue macrophage infiltration and activation. Diabetes 2009;58: 2006-2017.

70 Fujisaka S, Usui I, Bukhari A, Ikutani M, Oya T, Kanatani Y, Tsuneyama K, Nagai Y, Takatsu K, Urakaze M, Kobayashi M, Tobe K: Regulatory mechanisms for adipose tissue M1 and M2 macrophages in diet-induced obese mice. Diabetes 2009;58:2574-2582.

71 Shaul ME, Bennett G, Strissel KJ, Greenberg AS, Obin MS: Dynamic, M2-like remodeling phenotypes of CD11c+ adipose tissue macrophages during high-fat diet-induced obesity in mice. Diabetes 2010;59:1171-1181.

72 Havel PJ: Update on adipocyte hormones: regulation of energy balance and carbohydrate/lipid metabolism. Diabetes 2004;53 (suppl 1):S143-S151.

73 Lötzer K, Döpping S, Connert S, Gräbner R, Spanbroek R, Lemser B, Beer M, Hildner M, Hehlgans T, van der Wall M, Mebius RE, Lovas A, Randolph GJ, Weih F, Habenicht AJ: Mouse aorta smooth muscle cells differentiate into lymphoid tissue organizer-like cells on combined tumor necrosis factor receptor-1/lymphotoxin beta-receptor NF-kap$\mathrm{paB}$ signaling. Arterioscler Thromb Vasc Biol 2010;30:395-402.

74 Sumiyoshi K, Mokuno H, Iesaki T, Shimada K, Miyazaki T, Kume A, Kiyanagi T, Kuremoto K, Watanabe Y, Tada N, Daida H: Deletion of the $\mathrm{Fc}$ receptors gamma chain preserves endothelial function affected by hypercholesterolaemia in mice fed on a high-fat diet. Cardiovasc Res 2008;80:463-470.

75 Zhao M, Wigren M, Dunér P, Kolbus D, Olofsson KE, Björkbacka H, Nilsson J, Fredrikson GN: FcgammaRIIB inhibits the development of atherosclerosis in low-density lipoprotein receptor-deficient mice. J Immunol 2010;184:2253-2260. 
-76 Shushakova N, Skokowa J, Schulman J, Baumann U, Zwirner J, Schmidt RE, Gessner JE: $\mathrm{C} 5 \mathrm{a}$ anaphylatoxin is a major regulator of activating versus inhibitory FcgammaRs in immune complex-induced lung disease. J Clin Invest 2002;110:1823-1830.

$>77$ Mold C, Rodic-Polic B, Du Clos TW: Protection from Streptococcus pneumoniae infection by C-reactive protein and natural antibody requires complement but not $\mathrm{Fc}$ gamma receptors. J Immunol 2002;168: 6375-6381.

78 Leon F, Contractor N, Fuss I, Marth T, Lahey E, Iwaki S, la Sala A, Hoffmann V, Strober W, Kelsall BL: Antibodies to complement receptor 3 treat established inflammation in murine models of colitis and a novel model of psoriasiform dermatitis. J Immunol 2006; 177:6974-6982.

79 Soruri A, Riggert J, Schlott T, Kiafard Z, Dettmer C, Zwirner J: Anaphylatoxin C5a induces monocyte recruitment and differentiation into dendritic cells by TNF-alpha and prostaglandin E2-dependent mechanisms. J Immunol 2003;171:2631-2636.
80 Fang C, Zhang X, Miwa T, Song WC: Complement promotes the development of inflammatory T-helper 17 cells through synergistic interaction with Toll-like receptor signaling and interleukin- 6 production. Blood 2009;114:1005-1015.

81 Gao Q, Jiang Y, Ma T, Zhu F, Gao F, Zhang P, Guo C, Wang Q, Wang X, Ma C, Zhang Y, Chen W, Zhang L: A critical function of Th17 proinflammatory cells in the development of atherosclerotic plaque in mice. J Immunol 2010;185:5820-5827.

82 Woodruff TM, Nandakumar KS, Tedesco F Inhibiting the $\mathrm{C} 5-\mathrm{C} 5 \mathrm{a}$ receptor axis. $\mathrm{Mol}$ Immunol 2011;48:1631-1642.

83 Manthey HD, Thomas AC, Shiels IA, Zernecke A, Woodruff TM, Rolfe B, Taylor SM Complement C5a inhibition reduces atherosclerosis in ApoE-/- mice. FASEB J 2011;25: 2447-2455.
84 Széplaki G, Varga L, Füst G, Prohászka Z: Role of complement in the pathomechanism of atherosclerotic vascular diseases. Mol Immunol 2009;46:2784-2793.

-85 Langer HF, Chung KJ, Orlova VV, Choi EY, Kaul S, Kruhlak MJ, Alatsatianos M, Deangelis RA, Roche PA, Magotti P, Li X, Economopoulou M, Rafail S, Lambris JD, Chavakis T: Complement-mediated inhibition of neovascularization reveals a point of convergence between innate immunity and angiogenesis. Blood 2010;116:4395-4403.

86 Bongrazio M, Pries AR, Zakrzewicz A: The endothelium as physiological source of properdin: role of wall shear stress. Mol Immunol 2003;39:669-675.

87 Vachharajani V, Granger DN: Adipose tissue: a motor for the inflammation associated with obesity. IUBMB Life 2009;61:424-430.

88 Rutkowski B, Szolkiewicz M, Korczynska J, Sucajtys E, Stelmanska E, Nieweglowski T, Swierczynski J: The role of lipogenesis in the development of uremic hyperlipidemia. Am J Kidney Dis 2003;41(3 suppl 1):S84-S88. 